\title{
Homeopathy for the treatment of gastrointestinal disorders in children
}

\author{
Cássia Virginia Garcia, Taiana Markoski \\ Pharmacy School, Federal University of Pampa - UNIPAMPA, Uruguaiana, Brazil
}

\begin{abstract}
Background: Colic and diarrhea are among the most common gastrointestinal disorders in childhood, which manifest spontaneously and acute. The allopathic treatment consists, in most cases, in the administration of the association homatropine-dimethicone to relieve colic, and oral rehydration and loperamide in cases of diarrhea [1,2]. The ineffectiveness of the conventional treatment and the possible adverse effects they may cause have led to increase the demand from children' parents for complementary and alternative therapies, and homeopathy can be one of the first choices in this disorders [3].
\end{abstract}

Aims: make a literature review evaluating the effectiveness of homeopathic treatment for colic and diarrhea in children, observing the relation between the main medicines prescribed in these disorders and their pathogenesis described in materia medica.

Methodology: a literature research was performed applying electronic database, including Medline, HomeoIndex, BIREME, LILACS, PubMed, SciELO, and ScienceDirect in the period from September to December 2010.

Results: Data found indicate that few studies are available in the literature to prove the effectiveness of homeopathic medicines for colic and diarrhea in children, but the applicability of this therapeutic modality seems to be useful, safe and low cost, which are important factors for less favored communities. Besides, studies concerning diarrhea are more frequent, not only because of its gravity, but also for the duration, which makes more adequate the monitoring, on the contrary to acute colic. The most cited medicines were Chamomilla, Nux vomica, Arsenicum album and Mercurius solubilis.

Conclusions: Homeopathy can be an important source of colic and diarrhea relief. However, more investigations should be performed in order to show parents how valuable this kind of therapy can be to children and the whole family.

Keywords: Homeopathy; Diarrhea; Infantile Colic.

\section{References:}

[1] Ferreira VJA. Neurological manifestations in the intoxication of infants by dimethicone plus homatropine: report of 6 cases. Arq. Neuropsiquiatr. 2001; 2(59-A): 238-241.[Portuguese].

[2] Silva P. Farmacologia. 7th ed. Rio de Janeiro (Brazil): Guanabara Koogan; 2006.

[3] Rossi E, Endrizzi C, Panozzo MA, Bianchi A, Da Frè M. Homeopathy in the public health system: a sevenyear observational study at Lucca Hospital (Italy). Homeopathy. 2009; 98(3): 142-148. 


\title{
Homeopatia para o tratamento de transtornos gastrintestinais em crianças
}

\author{
RESUMO
}

Introdução: a cólica e a diarreia estão entre os transtornos gastrintestinais mais comuns da infância, os quais se manifestam de forma espontânea e aguda. O tratamento alopático consiste, na maioria dos casos, na administração da associação homatropina-dimeticona para o alívio da cólica, e, reidratação oral e loperamida nos casos de diarreia [1,2]. A falta de eficácia do tratamento convencional e os possíveis efeitos adversos que o mesmo pode causar têm levado ao aumento da demanda por parte dos pais por terapias alternativas e complementares e a homeopatia pode ser uma das primeiras escolhas nestas situações [3].

Objetivos: fazer uma revisão da literatura avaliando a efetividade do tratamento homeopático para cólica e diarreia em crianças, observando a relação entre os principais medicamentos prescritos nestes casos e suas patogenesias descritas na matéria médica.

Metodologia: foi realizada uma pesquisa na literatura usando as bases de dados eletrônicas, incluindo Medline, Homeoindex, BIREME, Lilacs, Pubmed, Scielo e Sciencedirect, no período de setembro a dezembro de 2010 .

Resultados: os dados encontrados indicam que poucos estudos estão disponíveis na literatura para provar a efetividade dos medicamentos homeopáticos em cólica e diarreia em crianças, mas a aplicabilidade desta modalidade terapêutica parece ser útil, segura e de baixo custo, que são fatores importantes para comunidades de baixa renda. Além disso, os estudos em relação a diarreia são mais frequentes, não apenas por sua gravidade, mas também pela duração, que torna mais adequado o monitoramento, ao contrário da cólica que é aguda. Os medicamentos mais citados foram Chamomilla, Nux vomica, Arsenicum album e Mercurius solubilis.

Conclusões: a homeopatia pode ser um importante recurso para o alívio da cólica e da diarreia. Entretanto, mais pesquisas devem ser realizadas a fim de mostrar aos pais quão valiosa este tipo de terapia pode ser para as crianças e toda a família.

Palavras-chave: homeopatia; diarreia; cólica infantil.

\section{(c) BY-NC-ND Licensed to GIRI}

Support: authors declare that this study received no funding

Conflict of interest: authors declare there is no conflict of interest

Correspondence author: Cássia Virginia Garcia, cassiavgarcia@yahoo.com.br, www.unipampa.edu.br

How to cite this article: Garcia CV, Markoski T. Homeopathy for the treatment of gastrointestinal disorders in children. Int J High Dilution Res [online]. 2011 [cited YYYY Month dd]; 10(36): 209-210 Proceedings of the XXV GIRI Symposium and VIII CBFH; 2011 Sep 04-07; Foz do Iguaçu (Brazil). GIRI and ABFH; 2011; Available from: http://www.feg.unesp.br/ ojs/index.php/ijhdr/article/view/503/515 